\title{
ANALYTICAL AND FIELD EVALUATION METHODS OF THE BEARING CAPACITY OF DEEP PILES AND BARRETTES IN SOFT SOIL AT ST. PETERSBURG
}

\author{
Rashid A. Mangushev \\ Chair of Geotechnics, Saint Petersburg State University of Architecture and Civil \\ Engineering; Vtoraya Krasnoarmeiskaya St. 4, St. Petersburg, 190005, Russia \\ ramangushev@yandex.ru
}

\begin{abstract}
The standard procedure of the field evaluation methods of the bearing capacity of piles used in Russian Federation is described.

A pilot deep pile (length $L=52.8 \mathrm{~m}$ and diameter $\mathrm{D}=1,2 \mathrm{~m}$ ) constructed under a multi-story building within large layers of soft soil is utilized as an example of the in-situ loading system at a construction site; the results of such a static test are presented and compared with analytical predictions of the bearing capacity for such a pile. Similarly, a pilot deep barrette with rectangular cross section $(3,3 \mathrm{~m} \times 1,1 \mathrm{~m})$ and a length of $65 \mathrm{~m}$ was also constructed at the same construction site with its bottom end reaching a layer of stiff Vendian clay (bed-rocks of pre-glacial origination). The tests of the pile were performed by using $\mathrm{O}$ - cells. The deformation sensors were mounted into the reinforced frame of the pile at 9 levels during the installation of the pile. The tests of the pilot barrette were performed in two stages. During the first stage the standard Top-Down tests were done along the whole length of the pile. During the second stage tests using O-cells were performed transferring the loading in two directions (up and down) after reaching maximal load. An O-cell was placed at the depth of $50 \mathrm{~m}$ within the layer of stiff clays.

The diagrams of the pile movement against the applied loading during the first and second test stages are presented together with the predicted total bearing capacity of the barrette found by employing different analytical methods.
\end{abstract}

\section{Keywords}

deep piles, barrettes, soft soils, tests by using $\mathrm{O}$ - cells, pile bearing capacity, field tests, soft soils

\section{Introduction}

The evaluation of the pile's bearing capacity by analytical methods and further checking of the results during field tests is an important stage of the pile foundation design. There are numerous analytical methods for the calculation of the bearing capacity of an individual pile which consider the geometry of the pile and the properties of the adjacent soil. However, quite often these calculated bearing capacity predictions differ from corresponding field tests results of such a pile under vertical loading. As a rule the calculated pile bearing capacity obtained by using Russian norms SNIP 2.02.03-85 is significantly lower than the bearing capacity obtained through standard vertical load testing in-situ (GOST 5686-94). Moreover, there are no Russian norms regarding field testing for barrettespiles.
During the construction of the foundation for the business center "OCHTA-CENTER" with a height of $396 \mathrm{~m}$, two pilot borrow piles were constructed having a diameter of 1,2 m and a of length $52,8 \mathrm{~m}$ and the protection of the external pipe; moreover, five pilot barrettes-piles, with a cross-section of $3,3 \times 1,0 \mathrm{~m}$ and a length of $65 \mathrm{~m}$ long, were also installed.

One of the tasks of the field tests was to determine the total bearing capacity of the borrow piles and barrette. Moreover, to be able to identify what portion of this total bearing capacity was contributed from the sides of the pile (friction) and what was the remaining portion contributed from the bottom of the pile.

2. Engineering and geological conditions of the area for pile tests

Along the depth of drilling $(170 \mathrm{~m})$ the following layers of the base were found: artificial sediments 
tgIV; lake-sea sediments $\mathrm{m}, \mathrm{IIV}$; lake-glacial sediments (upper sediments) of the Baltic glacial lake Iglllb; lake-glacial sediments of Luga moraine (lower sediments) Iglllz; glacial sediments of Luga moraine gllllz; mainland Vendian clays Vkt2. The main average properties of the soil are given in Table 1.

3. Evaluation of the bearing capacity of the pilot pile, diameter $D=1,2 \mathrm{~m}$ and length $L=52,8 \mathrm{~m}$

The analytical bearing capacity of the friction pile is calculated according the formula in accordance with the Russian norms.

Where:

$$
F_{d}=\gamma_{c}\left[\gamma_{c R} R A+u \sum \gamma_{c f} f i h i\right]
$$

$\gamma_{c}-$ coefficient of the work conditions of pile in soil, for driving piles $\gamma_{c}=1$;

$R$-calculated soil resistance under the lower end of the pile; $A$ - area of the cross section of the pile, $\mathrm{m}^{2} ; u$ - perimeter of the cross section of the pile, $\mathrm{m}$; $f_{1}$ - calculated resistance of $i$-layer of the soil along the side surface of the pile, $\mathrm{kPa} ; h_{1}$ - thickness of the $i$-layer touching the side surface of the pile, $\mathrm{m}$, taken as $h_{i}<2 \mathrm{~m} ; \gamma_{c R}, \gamma_{c f}$ - coefficients of the work conditions of soil under the lower end and along the side surface of the pile, considering the method of pile manufacturing.

The piles with the diameter $1,2 \mathrm{~m}$ and length $52,8 \mathrm{~m}$ under vertical static loading were tested using hydraulic jacks till maximal loading 3500 tones $(35000 \mathrm{kN})$ For this purpose, a special loading platform was constructed from crossed steel beams and supporting a 33 drill-injected anchors like steel piles "Titan" (Fig.1).

According to the Russian norms (GOST 5686-94) the total bearing capacity of the pile is calculated from the loading applied on the pile when it causes the vertical deformation equal $\Delta=20 \mathrm{~mm}$. In the examined case it corresponds to the measured loading value equal to $\mathrm{Fd}$, site $=25000 \mathrm{kN}$ (see Figure 2). Figure 2 depicts the obtained during testing load-deformation performance of the studied pile.
Analytical calculations against formula (1) resulted in a total bearing capacity value for this pile equal to $\mathrm{Fd}$,calc $=8320 \mathrm{kN}$ (SNIP 2.02.03-85, SP $50-102-2003$ ) $71 \%$ of the total bearing capacity $(5985 \mathrm{kN})$ refers to the end of the pile and only $29 \%$ of the total bearing capacity $(3145 \mathrm{kN})$ referred to the surface side.

The predicted load-deformation behavior obtained by employing the software PLAXIS 3D (a widely known geotechnical programme based on the FEM) - is shown in figure 3. The total bearing capacity value of the studied pile obtained from this methodology is equal to $\mathrm{Fd}$,plaxis $=11000 \mathrm{kN}$ (Fig. 3). In calculations under program PLAXIS soils characteristics given in tab. 1 and value of the vertical loadings applied to pile according to values specified on fig. 2 and 3 were taken into account.

In table 2, the predicted total bearing capacity values obtained as explained before are compared with the measured pile vertical loading capacity measured during the in-situ testing.

The predicted tested pile total bearing capacity values, which were obtained by different methods, are listed in Table 2 column (2) and are compared

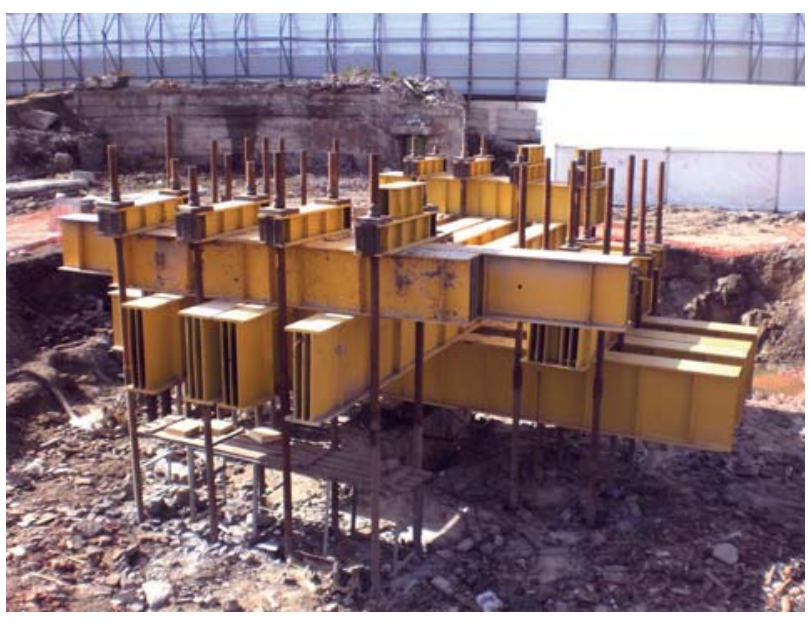

Fig. 1. General view of the loading platform for testing the piles with vertical static loading

Table 1

The main average properties of the soil

\begin{tabular}{|c|c|c|c|c|c|c|c|c|c|}
\hline $\mathrm{N}$ & Soil type & \begin{tabular}{|c|}
$\begin{array}{c}\text { Geological } \\
\text { Index }\end{array}$ \\
\end{tabular} & $\begin{array}{c}\mathrm{Y} \\
\mathrm{KN} / \mathrm{M}^{3} \\
\end{array}$ & W & e & $\mathrm{I}_{\mathrm{L}}$ & $\begin{array}{c}\mathrm{E} \\
\mathrm{MPa}\end{array}$ & $\begin{array}{c}\varphi, \\
\text { degree }\end{array}$ & $\mathrm{c}, \mathrm{MPa}$ \\
\hline 1 & Fill soil & $\operatorname{tg}_{\mathrm{IV}}$ & 17,5 & - & & & & & \\
\hline 2 & Sea and lake sediments & $\mathrm{m}, \mathrm{I}_{\mathrm{IV}}$ & 19,6 & 0,256 & 0,68 & 0,71 & 14 & 24 & 0 \\
\hline 3 & Upper lake-glacial sediments & $\lg _{\text {III b }}$ & 18,6 & 0,360 & 0,98 & 1,1 & 4.5 & 7 & 0,006 \\
\hline 4 & Lower lake-glacial sediments & $\lg _{\text {III } z}$ & 20,4 & 0,220 & 0,60 & 0,87 & 10,5 & 17 & 0,03 \\
\hline 5 & Moraine sediments & $g_{\text {IIII }}$ & 21,5 & 0,160 & 0,43 & 0.25 & 17 & 22 & 0.036 \\
\hline 6 & Deployed Vendian clays* & $\mathrm{V}_{\mathrm{kt2}}^{1}$ & 21,4 & 0,176 & 0,50 & $-0,35$ & 16 & 14 & 0,13 \\
\hline 7 & Not deployed Vendian clays & $\mathrm{V}_{\mathrm{kt} 2}^{2}$ & 22,3 & 0,129 & 0,37 & $-0,79$ & 113 & 22 & 0,84 \\
\hline
\end{tabular}

Deployed soil - soil having infringements, cracks and inclusions 


\section{Architecture and Engineering Volume 1 Issue 1}

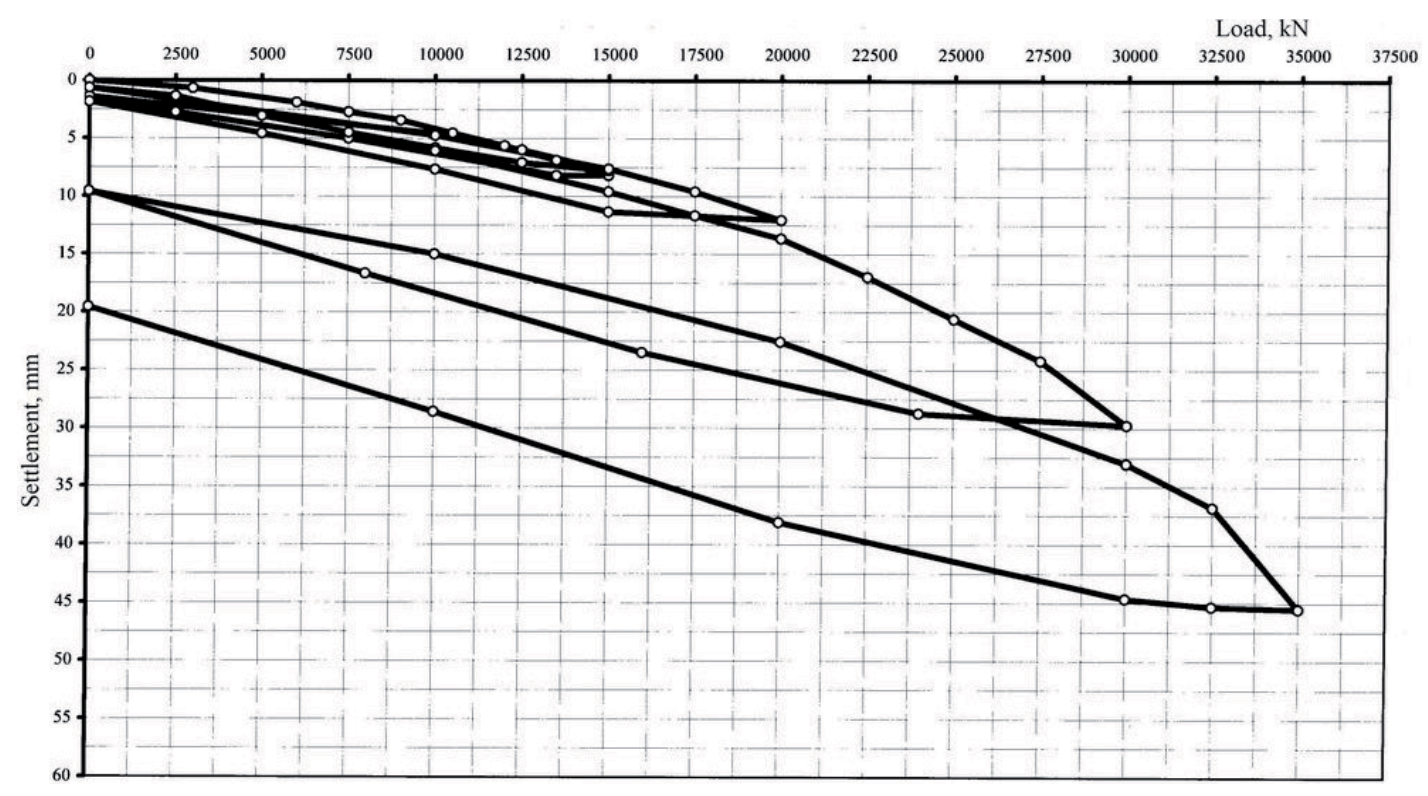

Fig. 2. Vertical static loading test results for the pile with $1.2 \mathrm{~m}$ diameter and a length of $52,8 \mathrm{~m}$



Fig. 3 Predicted vertical load-deformation performance of the tested pile obtained by the PLAXIS 3D software

Table 2

Predicted and measured Total bearing capacity of the test pile ( $D=1,2 \mathrm{~m}$ and L-52,8 $\mathrm{m}) F_{d}$, $\mathrm{kN}$

\begin{tabular}{|l|c|c|}
\hline \multicolumn{1}{|c|}{ Description of bearing capacity values } & $\begin{array}{c}\text { Total bearing capacity } \\
\text { of the test pile }(\mathrm{kN})\end{array}$ & $\begin{array}{c}\text { Ratio of measured } / \\
\text { predicted values }\end{array}$ \\
\hline$(1)$ & $(2)$ & $(3)$ \\
\hline Predicted value $\boldsymbol{F}_{d, \text { calc }}$ according to (SNIP 2.02.03-85, SP 50-102-2003) & 8320 & 3.005 \\
\hline Calculated value based on PLAXIS 3D, $\boldsymbol{F}_{d^{\prime} \text { PLAXIS }}$ & 11000 & 2.273 \\
\hline Measured value during the field tests, $\boldsymbol{F}_{d, \text { site }}$ & 25000 & 1.0 \\
\hline
\end{tabular}

to the measured total bearing capacity value which is listed in the same table. In column (3) of table 2 the ratio of the measured over the predicted values is also listed. As can be seen, the measured total bearing capacity value of the tested pile is 2.273 times larger than the PLEXIS 3D prediction and 3.005 times larger than the prediction based on the Russian norms.
4. The evaluation of the bearing capacity of pilot barrette, size $1 \times b=3,3 \times 1,0 \mathrm{~m}$ length $L=65 \mathrm{~m}$

The pilot test of the barrette, size $1 \times b=3,3 \times 1,0 \mathrm{~m}$ length $L=65 \mathrm{~m}$ with its bottom located in the mainland soil - Vendian clays Vkt2 was performed at the same construction site. It was supposed to use "O-Cell" and deformation sensors for the test. The plan of their location is given in Fig 4. 


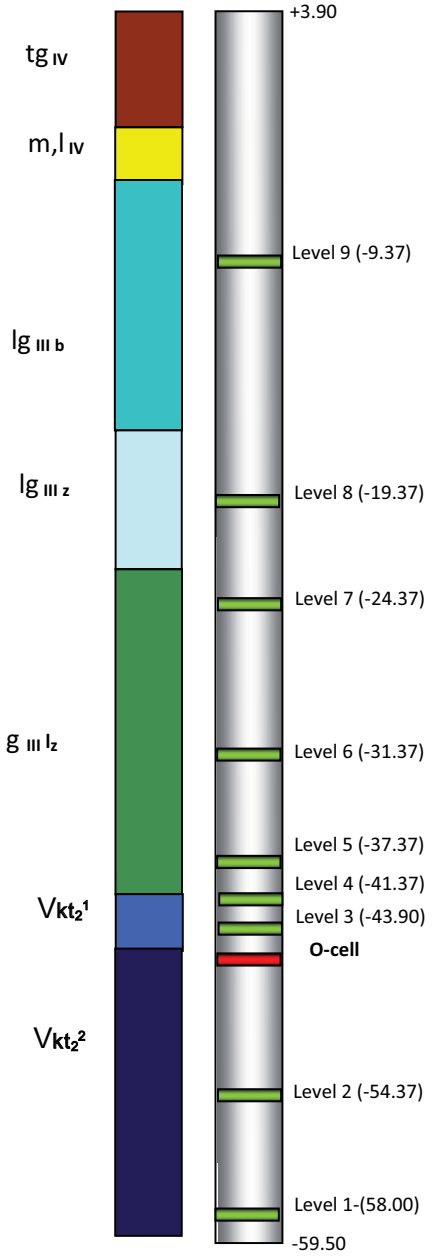

Fig.4. Plan of the location of O-cell and sensors of moving on the pilot barrette
The pilot barrette was tested by applying vertical static loading in two stages. At the first stage the barrette was tested by vertical loading applied to the top of barrette (top-down). After reaching maximal possible loading the second stage started using "O-cell" on the absolute level -45.00. Due to that the loading was transferred in two directions - up and down.

The test results of the pilot barrette at the first stage of loading, when the "Top-down" method was applied, are given in Fig.5. At the maximal loading $30000 \mathrm{kN}$ the settlement was less than $20 \mathrm{~mm}$.

The extrapolation of the diagram loadingsettlement till horizontal line, corresponding $\Delta=20 \mathrm{~mm}$ allows to evaluate the total bearing capacity of the pilot barrette during its initial loading Fd,Top-Down $=32000 \mathrm{kN}$.

The analytical calculations of pilot barrette according the formula (1) (SNIP 2.02.03-85, SP 50-102-2003) gave the total bearing capacity $\mathrm{Fd}, \mathrm{calc}=31244$, the result close to the test results according Top-down method.

The calculations by PLAXIS 3D showed the total bearing capacity of barrette Fd,PLAXIS $=27800 \mathrm{kN}$ (Fig.6), which is less than the results received by "Top-down" method.

The results received by the tests with O-cell, made after Top-down tests, are shown in Fig.7.

The red line in Fig.7 corresponds to the Topdown test of the lower part of the pile and allows evaluating the bearing capacity of the bottom end of the barrette.

\section{Load, kN}

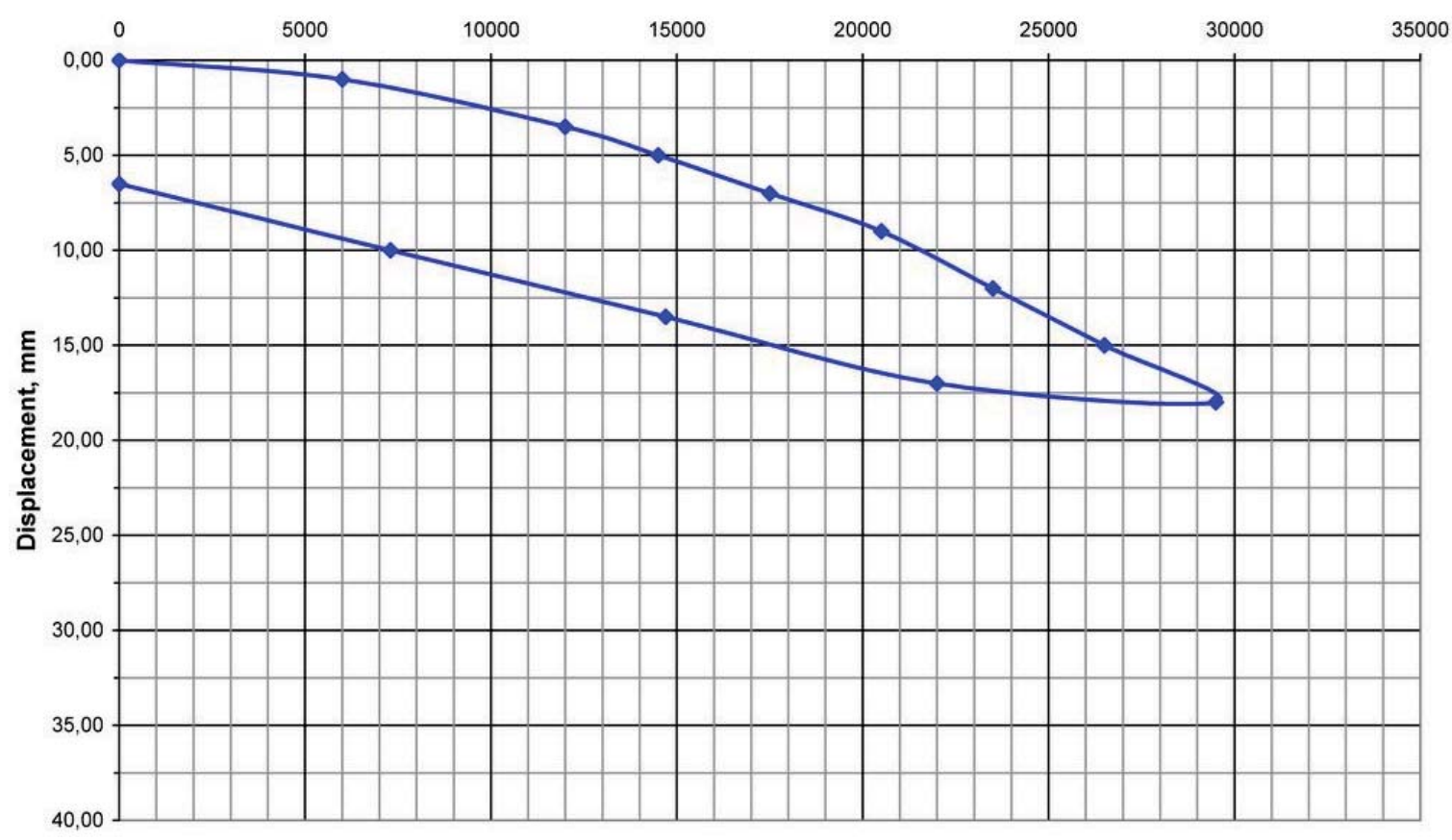

Fig 5. Moving of barrette due to applied vertical loading 


\section{Architecture and Engineering Volume 1 Issue 1}

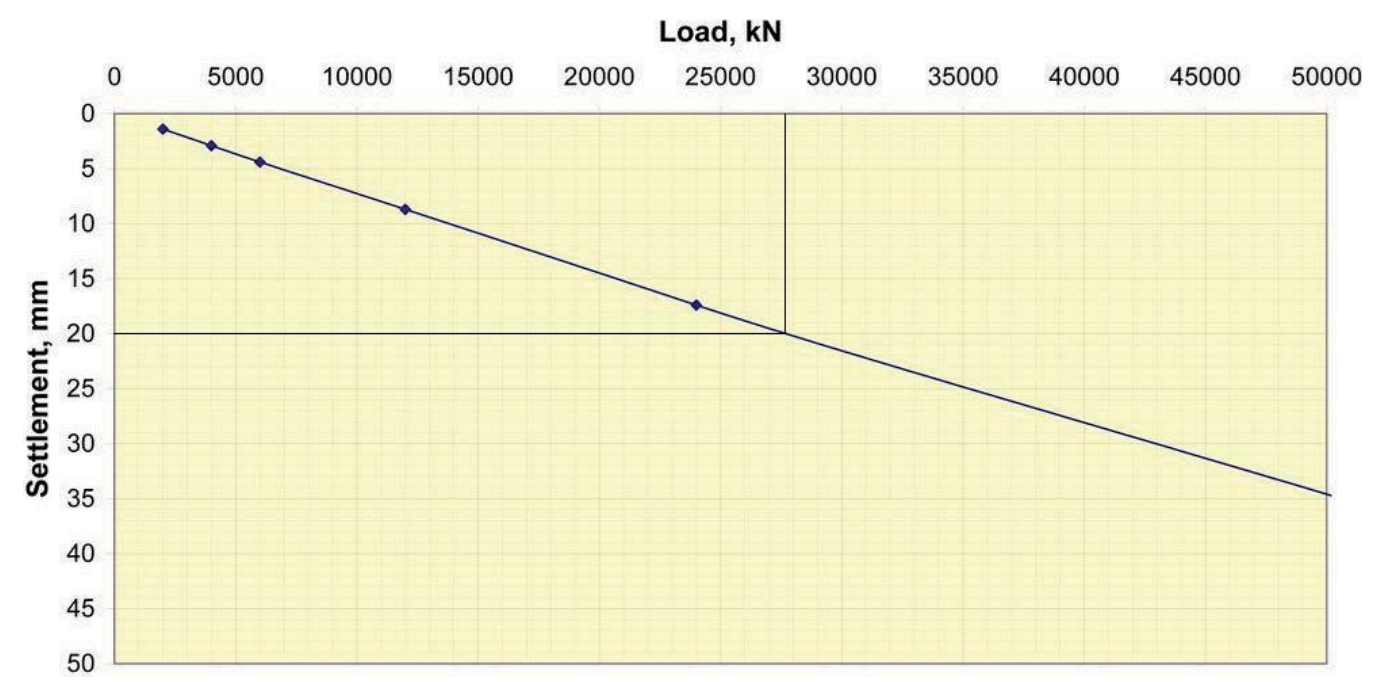

Fig.6. Calculation results of the vertical loading (Top-down) made by PLAXIS 3D



Fig.7. The diagram of vertical movement of the pile due to applied vertical loading by the "O-cell» method

Table 3

Predicted and measured Total bearing capacity of the test barrette $3,3 \times 1,0 \mathrm{~m}$ and L-65, $F_{d}(\mathrm{\kappa N})$ for the first and next loading

\begin{tabular}{|c|c|c|c|}
\hline Description of bearing capacity & $\begin{array}{c}\text { Total bearing } \\
\text { capacity of the } \\
\text { test barrette }(\mathrm{kN})\end{array}$ & $\begin{array}{c}\text { Ratio of measured } \\
\text { (first loading / } \\
\text { predicted values }\end{array}$ & $\begin{array}{c}\text { Ratio of measured } \\
\text { (next loading) / } \\
\text { predicted values }\end{array}$ \\
\hline (1) & $(2)$ & (3) & $(4)$ \\
\hline $\begin{array}{l}\text { Predicted value } F_{d, \text { calc }} \text { (SNIP 2.02.03-85 and SP 50-102- } \\
\text { 2003) }\end{array}$ & 31244 & 1.024 & 1.360 \\
\hline Calculated value based on PLAXIS 3D, $F_{d, \text { PLAXIS }}$ & 27800 & 1,151 & 1,529 \\
\hline Results of the field tests Top-Down (first loading), $F_{d}$ ' Top-Down & 32000 & - & \\
\hline $\begin{array}{l}\text { Results of the field tests «O-cell» } \\
\text { (next loading), } F_{d, \text { O-cell }} \\
F_{d f \text {, O-cell }} \\
F_{d R \text {, O-cell }}\end{array}$ & $\begin{array}{l}42500 \\
29500 \\
13000 \\
\end{array}$ & - & \\
\hline
\end{tabular}


The extrapolation of the upper part of the diagram "loading" (blue line) till the crossing with horizontal axis, which correspond to $\Delta=20 \mathrm{~mm}$ allows to evaluate the bearing capacity of the side surface of the pile as $F_{d f, o-c e l l}=29500 \mathrm{kN}$. The lower part of the diagram (red line) shows the bearing capacity of the bottom end of the barrette at least $F_{d d R, o-c e l l}=13000 \mathrm{kN}$.

The total bearing capacity of the pile calculated by this test method is at least $F_{d, o-c e l l}=42500 \mathrm{kN}$

As it was expected the total bearing capacity of the barrette during the next loading by the "O-cell" method was higher than during the first loading by the "Top-down" method (by more than 30\%).

The test results given by the "O-cell" method and by analytical calculations are presented in summary in Table 3.

\section{Conclusions}

1. The tests results showed that the measured bearing capacity of the pilot pile with diameter
$\mathrm{D}=1,2 \mathrm{~m}$ and length $\mathrm{I}=52,8 \mathrm{~m}$ was significantly higher (more than 200\%) than the corresponding value calculated either according to Russian norms (SNIP 2.02.03-85, SP 50-102-2003) or by PLAXIS 3D.

2. The tests results showed that the measured bearing capacity of the pilot pile with a cross section $3,3 \mathrm{~m} \times 1,0 \mathrm{~m}$ and length $\mathrm{L}=65 \mathrm{~m}$ was quite close to the corresponding value predicted according to Russian norms (SNIP 2.02.03-85 and SP 50-1022003) (this calculated value is only $2,5 \%$ smaller than the measured value). The corresponding value calculated by PLAXIS $3 \mathrm{D}$ is $15 \%$ smaller than this measured value.

3 . The bearing capacity of the soil at the bottom of the barrette $(13000 \mathrm{kN})$ represent one half $(1 / 2)$ was of the bearing capacity offered by side surface of the barrette $(29000 \mathrm{kN})$ in spite of the thick layers of soft soil that lie all along the length of the tested barrette.

\section{References}

Mangushev R., Osokin A. (2010), Geotechnics of Saint-Petersburg. Publ. House ASV.

Mangushev R., Yershov, A., Osokin A. (2010), Modern Pile Construction Technology. 2nd Edition, revised and updated. Publishing House of Association of Construction Higher Education Institutions, Moscow, Russia.

Mangushev R., Usmanov R, Osokin A. (2015), Geotechnical problems in designing buildings and structures in soft water-saturated soil conditions (by example of northern and southern regions) Monograph. Academic Publ. House LAMBERT.

MNTKS (Mezhgosudarstvennaja nauchno-tehnicheskaja komissija po standartizacii i tehnicheskomu normirovaniju $v$ stroitel'stve) (1995) GOST 5686-94 Soils. Field test methods by piles. MNTKS, Moscow, RF

Gosstroj SSSR (1985) SNIP 2.02.03-85 Pile Foundation.

Gosstroj Rossii (Gosudarstvennyj komitet Rossijskoj Federacii po stroitel'stvu i zhilishhno-kommunal'nomu kompleksu) (2004) SP 501022003 Design and Construction of Pile Foundations. Gosstroj Rossii, Moscow, RF 